\title{
Metalloproteinek fémkötőhelyein alapuló oligopeptidek, mint potenciális toxikus fémion érzékelők
}

\author{
SZEKERES Levente ${ }^{\mathrm{a}}$, SZUNYOGH Dániel ${ }^{\mathrm{b}}$, GALBÁCS Gábor ${ }^{\mathrm{a}}$ és JANCSÓ Attila ${ }^{\mathrm{a}}$,* \\ ${ }^{a}$ SZTE Szervetlen és Analitikai Kémiai Tanszék, Dóm tér 7, 6720 Szeged, Magyarország \\ ${ }^{b}$ MTA-SZTE Bioszervetlen Kémiai Kutatócsoport, Dóm tér 7, 6720 Szeged, Magyarország
}

\section{Bevezetés}

A környezetben megjelenő toxikus fémionok lehetnek természetes eredetüek, de származhatnak antropogén forrásokból is. Ezek a fémionok a környezetben különböző átalakulásokon mehetnek át, ami befolyásolja megjelenési formájukat, mobilitásukat, oldhatóságukat és ennek megfelelöen bioelérhetőségüket is. ${ }^{1}$ Toxicitásuk miatt a táplálékláncba kerülésük jelentős kockázati tényezőt jelent a tápláléklánc összes szereplője számára. Mindez elengedhetetlenné teszi hatékony kimutatásukat és meghatározásukat, szükség esetén eltávolításukat a szennyezett közegekből, továbbá a mérgezések kezelését, a detoxifikálást. A fémionok vizes környezeti mintákból vagy biológiai fluidumokból történő kimutatására elterjedten használt robusztus, (nagy)müszeres analitikai kémiai eljárások melletti alternatívaként egyre nagyobb figyelem fordul kémiai / biokémiai szenzorok fejlesztése felé. Ezekben jól megtervezett molekulák fémion megkötése az adott fémion kimutatására / mennyiségi meghatározására alkalmas (pl. optikai) jelet produkál. ${ }^{2-4}$ A területen belül is különösen érdekes bio-inspirált molekulák, illetve rendszerek receptorként történő alkalmazása, melyek a „természet által kódoltan” hordozhatják egy szenzor számára kulcsfontosságú sajátságokat, az érzékenységet és a szelektivitást. Oligopeptidek, fehérjék és enzimek, vagy akár egyszerübb sejtek, fémionokkal adott szelektív reakcióik révén (bio)kémiai szenzorok ígéretes receptorai lehetnek. A szakirodalomban számos összefoglaló közlemény tárgyalja ilyen típusú receptorok optokémiai szenzorokban történő alkalmazását. ${ }^{5-9}$ A szintetikus oligopeptid szenzorok ugyan drágábbak, mint a sejt alapúak, azonban rendkívül érzékennyé és szelektívvé tehetők. Emellett az optimális müködési körülmények tekintetében alkalmazásuk rendszerint jóval kevésbé korlátozott, mint akár a sejt, akár a fehérje alapú szenzoroké.

A fluoreszcenciás elven működő fémion-szenzorok meglehetősen népszerűek, ${ }^{2,3,5,10}$ köszönhetően előnyös tulajdonságaiknak, például (i) érzékenység, (ii) egyszerü alkalmazhatóság, (iii) a lumineszcens tulajdonságok finom-hangolásának számos lehetősége, és nem utolsó sorban (iv) mérsékelt költségük. ${ }^{2}$ Fluoreszcens szenzor molekulák kiválóan alkalmazhatók fémionok kimutatására / mérésére élő rendszerekben is. ${ }^{6,11}$ Így nem meglepő, hogy a peptid típusú receptoron alapuló fémion érzékelők is leginkább fluorofór csoporto(ka)t tartalmaznak jelképző elemként. ${ }^{5-7,9,12}$ A fluoreszcenciás elven működő fémion-szenzorokat a fémion-kötőhely és a fluorofór csoport(ok) egymáshoz viszonyított helyzete alapján három nagyobb csoportba sorolhatjuk. ${ }^{13} \mathrm{Az}$ ún. I. Típusú. érzékelökben maga a fluorofór a fémion-kötő ligandum. A peptid alapú szenzorok szinte kizárólag a II. illetve III. típusba sorolhatók (1. Ábra). A II. Típusú molekulákban a fluorofór csoporthoz közvetlenül vagy egy „,spacer” révén kapcsolódik a fémion felismerő egység. A III. típusú érzékelőkben a receptorhoz kapcsolódó két egység, egy fluorofór és egy másik elem között alakul ki kapcsolat. Ha ez a két elem megfelelő fluorofór párt alkot, FRET (fluorescence resonance energy transfer) effektus jöhet létre, illetve a fluorofór kölcsönhatása a másik elemmel teljesen új kémiai minőséget is létrehozhat (excimer vagy exciplex képződik), amely egy új fluoreszcencia sáv megjelenését eredményezi. ${ }^{3}$
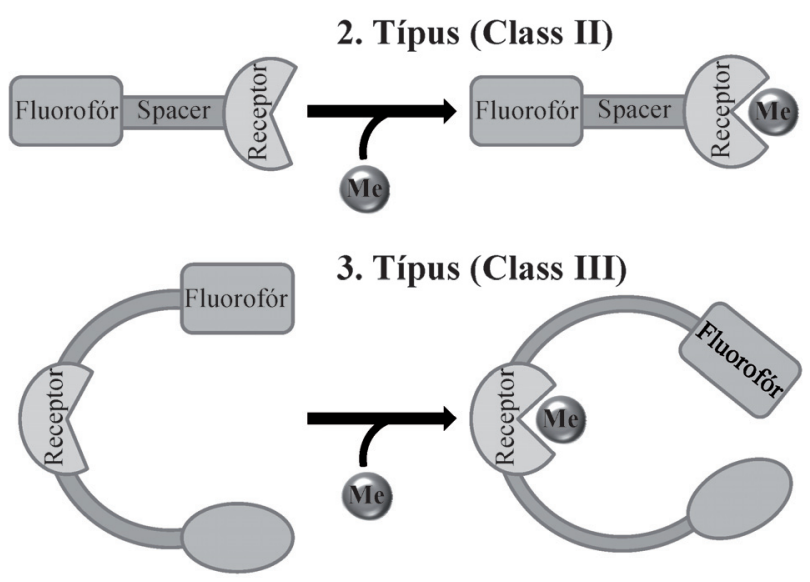

1. Ábra. A peptid fémion-felismerő egységet tartalmazó fémion-érzékelők két jellemző típusa

Számos publikáció igazolja a fenti szerkezeti csoportokba sorolható fluorofór-jelzett peptidek alkalmazhatóságát fémionok érzékelésére. Müködési elvük szerint „TURN ON" választ adó CHEF (chelation-enhanced fluorescence), ${ }^{14-17}$ „TURN OFF” jellegü CHEQ (chelation-enhanced quenching), ${ }^{17,18}$ illetve FRET típusú szenzorokat is vizsgáltak. ${ }^{19,20}$ A szenzorikai alkalmazhatóság szempontjából ideális „TURN ON” választ, de a „TURN OFF" effektust is a fluorofór gerjesztett állapotának HOMO szintje és a receptor HOMO ill. LUMO 
pályái közötti belső elektron transzfer folyamat, az ún. PET (photoinduced electron transfer) ki/be kapcsolása okozhatja (2. Ábra). ${ }^{21}$ Mindenképpen meg kell jegyezni, hogy CHEF vagy CHEQ hatást más mechanizmusok is eredményezhetnek. ${ }^{3,6}$ A FRET mechanizmus alapfeltétele, hogy a gerjesztett fluorofór (donor) emissziós sávja átfedjen a másik, alapállapotú fluorofór (akceptor) valamely abszorpciós sávjával, melynek révén dipól-dipól kölcsönhatáson alapuló sugárzásmentes rezonancia energia átmenet tud létrejönni a két molekularészlet között. A transzfer eredményeként az akceptor csoport fluoreszcens emissziója erösödik, míg a donor emissziós intenzitása csökken (2. Ábra). ${ }^{3,10}$ A FRET kialakulásának másik fontos feltétele, hogy a csoportok belül legyenek a kölcsönhatás hatótávolságán, az ún. Förster-távolságon, melyet a fémion-megkötése által okozott konformáció változás biztosíthat. Mivel a fémion-indukálta FRET megvalósulásához több feltétel együttes teljesülése (erős fémion-koordináció valamint a donor és akceptor csoportok kellő közelségbe kerülése a fémion-megkötődés hatására) szükséges, ezért az ilyen típusú szenzorokkal nagyobb eséllyel nyerhető fémion-szelektív válasz.
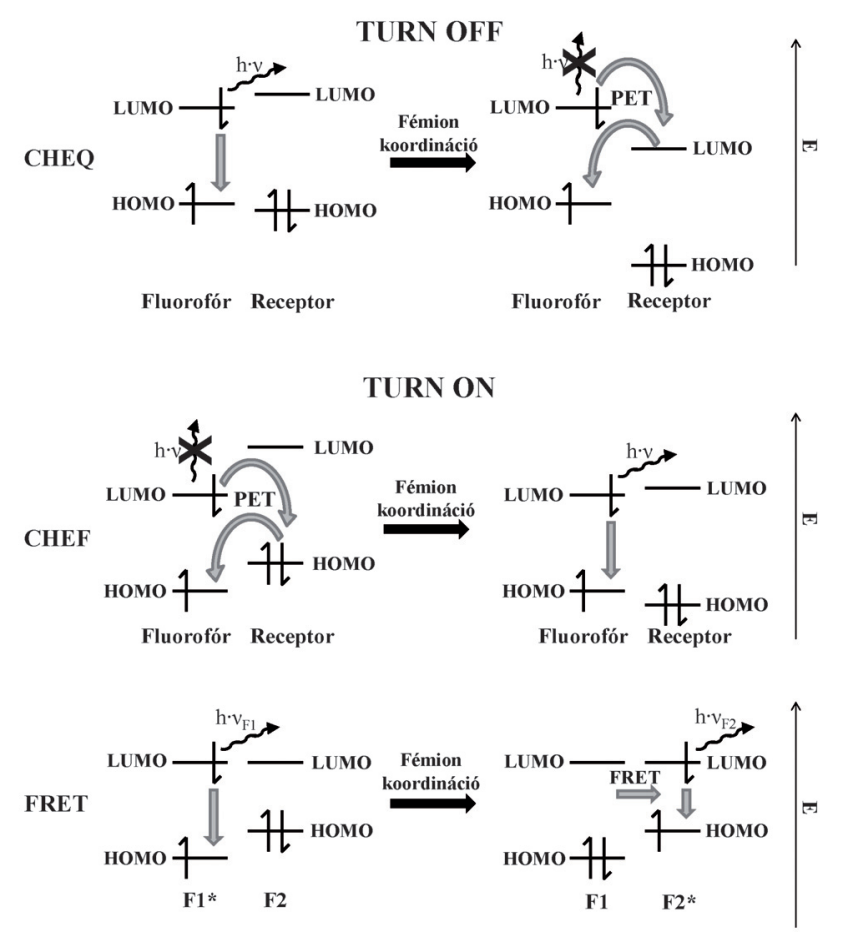

2. Ábra. A PET be-, ill. kikapcsolásával működő „TURN OFF” és „TURN ON”, valamint FRET szenzorokra jellemző molekulapálya energiaszintek a fémion megkötődése előtt és után ${ }^{10,21}$

A fémionok érzékelésére potenciálisan alkalmas fluoreszcens peptideket bemutató munkák rendszerint nagy hangsúlyt fektetnek a rendszerek analitikai kémiai szempontból történő leírására. A fémionokkal képződő komplexek oldatbeli speciációjának feltérképezése azonban szinte mindig hiányzik ezekből a munkákból, noha ennek esszenciális jelentősége lenne a vegyületek alkalmazhatósági körülményeinek ( $\mathrm{pH}$ - és koncentráció-tartomány, fémion-ligandum arány) megállapítása, vagy a molekulák továbbfejlesztése szempontjából. Ugyancsak ritka, hogy az érzékelő rendszereket immobilizált formában is vizsgálnák, ${ }^{18,22}$ ami viszont a szenzorikai alkalmazásuk szempontjából lenne kulcsfontosságú.

Csoportunk az utóbbi években számos olyan, cisztein tartalmú oligopeptid előállításával és vizsgálatával foglalkozott, melyek szekvenciáit nehézfémionok megkötésében szerepet játszó (vagy arra potenciálisan alkalmas) fehérjék (szabályzó, szállító vagy dajka fehérjék) inspirálták. A peptidek jelentős ,szoft” fémion affinitását kihasználva, módosításuk révén olyan vegyületek fejleszthetők, melyek toxikus fémionok hatékony, szelektív érzékelésére alkalmasak lehetnek. A megfelelő előállítási metódussal, ill. jól megtervezett módosításokkal (fluorófor csoportok beépítésével) mind a fémion-megkötésre adott válasz, mind a szilárd hordozón történő rögzítés biztosítható. Jelen közlemény az ezen a területen végzett munkáinkról és eddigi eredményeinkről ad összefoglaló jellegü áttekintést.

\section{A CueR fémszabályzó fehérjék fémion-kötő szakaszát modellező oligopeptidek vizsgálata}

A fémionok sejten belüli koncentrációjának érzékelése és szabályzása alapvető fontosságú az élő szervezetek, így a baktériumok számára is, fémion-homeosztázisuk fenntartásához. ${ }^{23}$ A prokariótákban ezt a szerepet a transzkripció szintjén müködő fémszabályzó, vagy más néven fémszenzor fehérjék töltik be. ${ }^{23-25}$ Ezek az ún. transzkripciós faktorok DNS-hez való kötődésükkel elősegítik vagy gátolják a fémionok felvételében, szállításában, eltávolításában, raktározásában vagy redoxi-átalakításában szerepet játszó fehérjék termelődését. ${ }^{23-25}$ Funkcionális szempontból ezen fehérjék két típusba sorolhatók, melyek a fémion felvételéért vagy a fémion eltávolításáért / tárolásáért felelős gének szabályzását végzik. ${ }^{23}$ Szerkezeti hasonlóságaik alapján tíz olyan fehérjecsaládot különböztetünk meg, melyeknek legalább egy eleme fémion-érzékelöként müködik. ${ }^{23} \mathrm{Az}$ egyik legnépesebb, és legváltozatosabb család a MerR, melynek tagjai transzkripciós aktivátorként müködnek. ${ }^{23,26}$ Ebbe a családba tartozik a baktériumok réz-eltávolítás folyamataiban résztvevő fehérjék termelödését irányító CueR is. ${ }^{27} \mathrm{~A}$ CueR valójában egy, a 11. elemcsoport egyértékü fémionjait szelektíven érzékelni képes, természetes bioszenzornak is tekinthető, hiszen a megfelelő gén transzkripcióját kimagasló érzékenységgel, de csak $\mathrm{Cu}^{+}-, \mathrm{Ag}^{+}-$vagy $\mathrm{Au}^{+}$-ionok jelenlétében aktiválja. ${ }^{28} \mathrm{~A}$ szelektív müködésben döntő szerepet játszik a molekula $C$-terminális végéhez közel elhelyezkedő 10-12 aminosavból álló fémion-kötő hurok, mely a végein elhelyezkedő két cisztein közvetlen koordinációja és egyéb kölcsönhatások révén lineáris koordinációs geometriába kényszeríti a fémionokat. ${ }^{28} \mathrm{~A}$ megfelelő fémion felismerése szempontjából tehát alapvető kérdés, hogy milyen módon képesek, illetve képesek-e egyáltalán egyéb fémionok megkötődni ezen a kötőhelyen? Vajon a fentebbi egyértékü ionokhoz hasonló koordinációs kémiai preferenciákkal bíró $\mathrm{Hg}^{2+}$ miért nem képes indukálni a fehérje müködését? A funkcionális szelektivitás a fémkötő doménhez történő 
koordinációban vagy az ennek következtében bekövetkező / elmaradó fehérje-szerkezetváltozásban keresendő inkább? A fenti kérdésekre adandó válaszok megtalálása nem csak a fehérje mechanizmusának megértése szempontjából érdekes, de az így nyert információkat fel lehet használni akár a szabályzási mechanizmuson alapuló bioszenzorok, akár a kötőhely továbbgondolt szekvenciáját, mint receptort alkalmazó fémion érzékelők fejlesztéséhez. A fémkötő domén fémion-kötő sajátságainak megismerése céljából több olyan peptidet is elöállítottunk, melyek szekvenciája valamely CueR fémkötő doménjével azonos, vagy azok egy-két aminosavban módosított variánsai (3. Ábra).
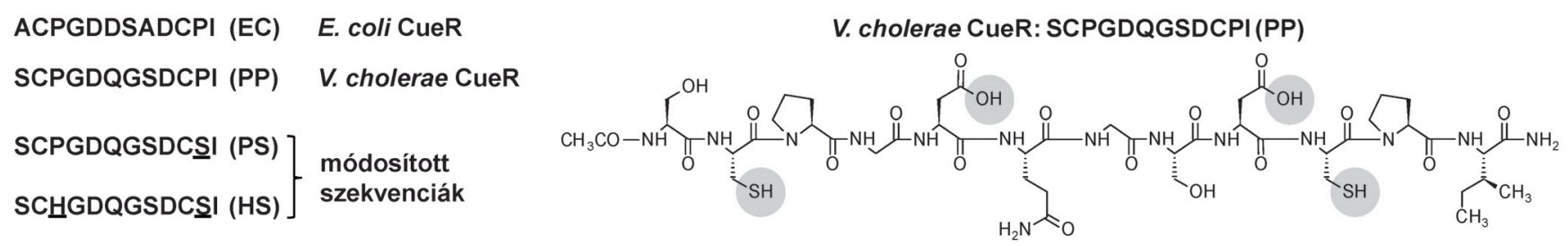

3. Ábra. Bakteriális CueR fehérjék fémkötő szakaszát alkotó peptidek (PP, EC) és variánsaik (PS, HS) szekvenciái (a módosítások hely aláhúzással jeölve), valamint egyikük sematikus szerkezete a potenciális fémion-kötőhelyek kiemelésével. (A peptidek szekvenciáiban az egyes aminosavakat az egyszerüség kedvéért mindenhol az egybetűs kódjaikkal jelöljük. (A: Ala, C: Cys, P: Pro, G: Gly, D: Asp, S: Ser, I: Ile, Q: Gln, H: His)

A módosítások olyan pozíciókban történtek, melyek a 12. elemcsoport fémionjaira érzékeny fehérjék fémkötöhelyeihez tették hasonlóbbá a peptidek szekvenciáit. Célunk az így nyert ligandumok és különböző karakterű egy- és kétértékü fémionok $\left(\mathrm{Ag}^{+}, \mathrm{Zn}^{2+}, \mathrm{Cd}^{2+}, \mathrm{Hg}^{2+}\right)$ kölcsönhatásának tanulmányozása volt pH-potenciometriás titrálások, valamint UV-, CD- és NMR-spektroszkópiai módszerek alkalmazásával.

\subsection{A CueR fémkötő szakaszát modellező peptidek kölcsönhatása $\mathrm{Zn}^{2+}{ }^{29-31}$ és $\mathrm{Cd}^{2+}$-ionokkal ${ }^{32,33}$}

Az oligopeptidek tiolcsoportjainak koordinációját a vizsgált átmenetifém-ionokhoz $\left(\mathrm{Hg}^{2+}\right.$ - és $\mathrm{Ag}^{+}$-ionok esetében is) UV-titrálásokkal követtük. Erre a kölcsönhatás létrejöttét egyértelműen jelző tiolátfémion töltésátviteli sávok 210-300 nm hullámhossz-tartományban való megjelenése ad lehetőséget. ${ }^{34}$ A különböző fémion-ligandum összetételü rendszerekben felvett spektrum-sorozatokkal igazoltuk, hogy mindkét fémion már enyhén savas pH-tartományban is képes leszorítani a tiolcsoportok protonjait és $\mathrm{pH} \sim 6$-ra kialakulnak a két koordinálódó tiolátot tartalmazó ML összetételü komplexek. Főként $\mathrm{Cd}^{2+}$-ionokkal ligandumfelesleg esetén egyértelműen kimutatható volt a két ligandum két-két tiolátcsoportjának részvételével kialakuló bisz-komplexek képződése (lásd a két abszorbancia-változás lépcsőt a 4. Ábrán).

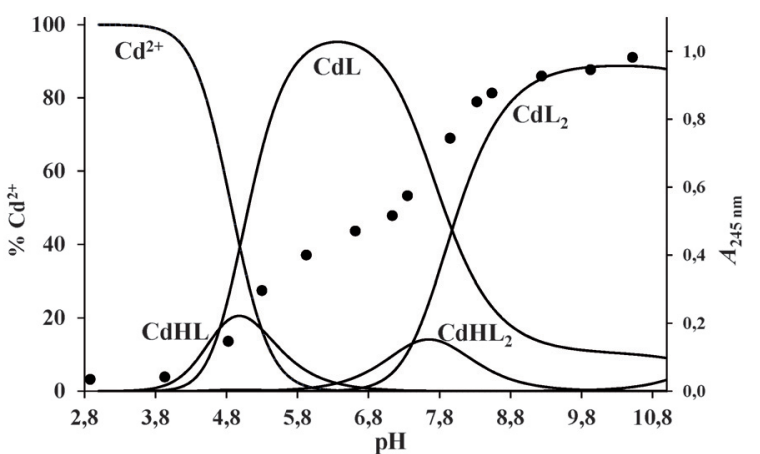

4. Ábra. $\mathrm{A} \mathrm{Cd}^{2+}$ - PP 0,5:1 összetételű rendszer részecske eloszlási diagramja $\left(c_{\mathrm{PP}}=110^{-4} \mathrm{M}\right)$ az UV-titrálások koncentrációjára szimulálva, valamint a 245 nm-en mért abszorbancia változás () pH-függése. (A diagramon $\mathrm{L}$ a teljesen deprotonált ligandumot, míg $\mathrm{H}$ a protont jelöli.)

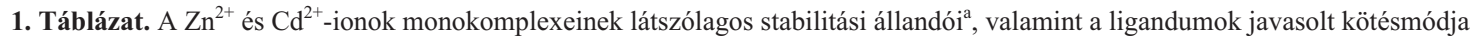

\begin{tabular}{|c|c|c|c|c|c|}
\hline \multirow[t]{2}{*}{ Ligandum } & \multicolumn{2}{|c|}{$\mathrm{Zn}^{2+}, \lg K^{\prime}$} & \multicolumn{2}{|c|}{$\mathrm{Cd}^{2+}, \lg K^{\prime}$} & \multirow{2}{*}{$\begin{array}{l}\text { A koordinációban } \\
\text { résztvevő csoportok }\end{array}$} \\
\hline & $\mathrm{pH}=7,0$ & $\mathrm{pH}=8,0$ & $\mathrm{pH}=7,0$ & $\mathrm{pH}=8,0$ & \\
\hline $\mathbf{P P}$ & 6,48 & 8,29 & 8,27 & 10,09 & $2 \times \mathrm{S}^{-}, \mathrm{COO}^{-},\left(\mathrm{COO}^{-}\right)$ \\
\hline PS & 6,53 & 8,39 & 8,20 & 10,03 & $2 \times \mathrm{S}^{-}, \mathrm{COO}^{-},\left(\mathrm{COO}^{-}\right)$ \\
\hline HS & 7,02 & 9,06 & 8,26 & 10,11 & $2 \times \mathrm{S}^{-}, \mathrm{N}_{\mathrm{im}},\left(\mathrm{COO}^{-}\right)$ \\
\hline EC & 6,90 & 8,85 & 8,57 & 10,51 & $2 \times \mathrm{S}^{-}, \mathrm{COO}^{-}, \mathrm{COO}^{-}$ \\
\hline
\end{tabular}

$$
{ }^{\mathrm{a}} K^{\prime}=\frac{\Sigma\left[\mathrm{M}^{2+}\right]_{\text {kötött }}}{\left[\mathrm{M}^{2+}\right]_{\text {szabad }} \Sigma[\mathrm{L}]_{\text {szabad }}}
$$

${ }^{1} \mathrm{H}-\mathrm{NMR}$ mérésekkel nem csak a tiolátcsoportok koordinációját, de legalább az egyik Asp-karboxilát részvételét is igazolni tudtuk a His aminosavat nem tartalmazó peptidek esetében. A HS peptid törzskomplexeiben $\left(\mathrm{ML}, \mathrm{ML}_{2}\right)$, illetve a protonált bisz-komplexekben $\left(\mathrm{MH}_{2} \mathrm{~L}_{2}, \quad \mathrm{MHL}_{2}\right)$ a hisztidin imidazolgyürüje - az oldallánc protonjai ${ }^{1} \mathrm{H}$-rezonanciáinak fémionok hatására történő kémiai-eltolódás változásai alapján - egyértelműen kötődik mindkét fémionhoz. pH-potenciometriás titrálásokkal meghatároztuk a fémion- 
peptid rendszerekre jellemző részecske-speciációt, valamint a képződő komplexek stabilitását. Az 4. Ábra a bisz-komplexek jelentős mennyiségben való képződését szemlélteti a $\mathrm{Cd}^{2+}-\mathbf{P P}$ 0,5:1 mólarányú rendszerben. A $\mathrm{Zn}^{2+}$ és $\mathrm{Cd}^{2+}$-ionokat valamint a PP ligandumot $1: 1: 1$ összetételben tartalmazó virtuális rendszerre szimulált részecskeeloszlás (5. Ábra) pedig a két fémion 1:1 összetételű komplexeinek stabilitás-különbségét tükrözi.

$\mathrm{Az}$ 1. Táblázat a négy peptid $\mathrm{Zn}^{2+}$ és $\mathrm{Cd}^{2+}$ (mono)komplexeinek $\mathrm{pH}=7,0$ és 8,0-ra számítható látszólagos stabilitási állandóit hasonlítja össze. Ezek alapján megállapítható, hogy a peptidek eltérő szekvenciái és donorcsoport-összetétele csak kis mértékben befolyásolják az adott fémionhoz való affinitásukat. A több potenciális donorcsoport jelenléte ugyan az EC esetében okoz szerény mértékű stabilitás-növekedést, azonban a His koordinálódásának hatása csak a $\mathrm{Zn}^{2+}$ komplexek stabilitásában látszik, feltehetőleg a $\mathrm{Zn}^{2+}$ imidazol-donor iránti jelentősebb preferenciája miatt, összevetve a $\mathrm{Cd}^{2+}$-ionnal. A His stabilitás-növelö hatása valószínüleg azért nem jelentkezik markánsabban a hisztidint nem tartalmazó peptidekhez képest, mert ezekben az Asp karboxilátok kötődése hasonló hozzájárulást eredményez.

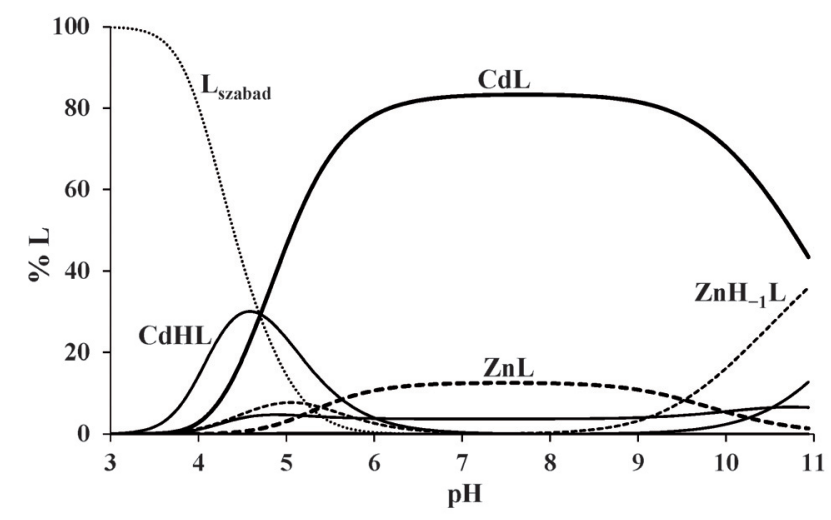

5. Ábra. A $\mathrm{Zn}^{2+}-\mathrm{Cd}^{2+}-$ PP 1:1:1 összetételű rendszerre szimulált részecske eloszlási diagram $\left(c_{\mathbf{P P}}=110^{-3} \mathrm{M}\right)$. $\mathrm{A} \mathrm{Zn}^{2+}$-ion komplexeit szaggatott, míg a $\mathrm{Cd}^{2+}$-komplexeket folytonos vonalak jelölik. . (A diagramon $\mathrm{L}$ a teljesen deprotonált ligandumot, míg $\mathrm{H}$ a protont jelöli.)

\subsection{A CueR fémkötő szakaszát modellező peptidek kölcsönhatása $\mathbf{H g}^{2+}{ }^{29-31}$ és $\mathbf{A g}^{+}$-ionokkal ${ }^{31,33}$}

A $\mathrm{Hg}^{2+}$-ionok extrém affinitása tiolátokhoz a tanulmányozott peptideknél is rendkívül stabilis komplexek képződését eredményezi. ${ }^{35}$ Az ekvimoláris összetételü $\mathrm{Hg}^{2+}$ - ligandum rendszerekben már pH 2 alatt az összes fémion kötött formában van jelen, és a peptidek kötésmódja UV- és ${ }^{1} \mathrm{H}-\mathrm{NMR}$ titrálásaink alapján a teljes pH-tartományban változatlan $\left\{2 \mathrm{Cys}-\mathrm{S}^{-}\right\}$típusú. Sem bisz-komplexek képződését, sem a HS His egységének koordinációját nem tudtuk kimutatni a komplex(ek)ben. Cirkuláris dikroizmus méréseink szerint a két tiolát $\mathrm{Hg}^{2+}$ kötés kialakulásával a ligandumok konformáció változást szenvednek, melynek révén feltehetőleg a CueR fémion-kötött állapotát is jellemző hurokszerü szerkezet jön létre, ami biztosítja a $\mathrm{Hg}^{2+}$ számára ideális (torzult) lineáris koordinációs geometriát. ${ }^{36}$
$\mathrm{Az} \mathrm{Ag}^{+}$- peptid rendszerekben az $\mathrm{Ag}^{+}$-ion a kétértékü fémionoktól markánsan eltérő koordinációs sajátságokat mutat. A fémion peptidekhez való koordinációját már 2-es pH körül egyértelmüen bizonyítják UV-, CD- és NMR méréseink, valamint a $\mathrm{pH}$-potenciometriás mérések során már savas $\mathrm{pH}-\mathrm{n}$ megfigyelt extra lúgfogyás a szabad ligandumhoz képest (6. Ábra). $\mathrm{Az} \mathrm{Ag}^{+}$- PP 1:1 mólarányú rendszerben meglepő módon $\mathrm{pH} \sim 5,5-6$ felett egy spektrofotometriásan és a titrálási görbéken is jól követhető deprotonálódási folyamat játszódik le, amely egyértelmüen a második tiolcsoport protonvesztéséhez és koordinálódásához rendelhető. Ez alapvető eltérés a kétértékü fémionokhoz képest, melyek $\mathrm{pH}=$ 6 körül már mindkét cisztein deprotonálódott tiolcsoportjához kötődnek. A 6-os és 8-as pH-n Ag+-ionok jelen- és távollétében felvett ${ }^{1} \mathrm{H}-\mathrm{NMR}$ spektrumok alátámasztják ezeket a megállapításokat. A 6-os pH-n mért spektrumokon a $\delta=$ 2,8-3,4 ppm-tartományban a kötött ciszteinre jellemző és a szabad ligandum cisztein $\mathrm{C}_{\beta} \mathrm{H}_{2}$ jeleire emlékeztető rezonanciák együttes, hasonló intenzitású jelenléte olyan részecskére utal, melynek két izomer szerkezetében az egyik, ill. másik Cys kötődik a fémionhoz, és a szerkezetek közötti ligandumcsere az NMR időskálán lassú (7. Ábra). pH = 8,8-nál már egyértelmű

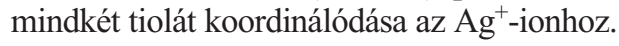

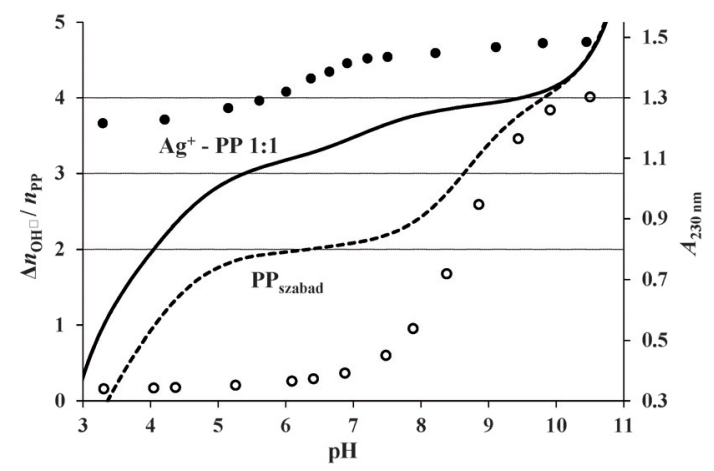

6. Ábra. $\mathrm{Az} \mathrm{Ag}^{+}-\mathbf{P P}$ 1:1 összetételű rendszer és a szabad PP ligandum-koncentrációra normált titrálási görbéi a ligandumra fogyott lúgekvivalenseket a $\mathrm{pH}$ függvényében ábrázolva, ill. a fémion jelen- () és távollétében () mért abszorbancia változás $230 \mathrm{~nm}$-en

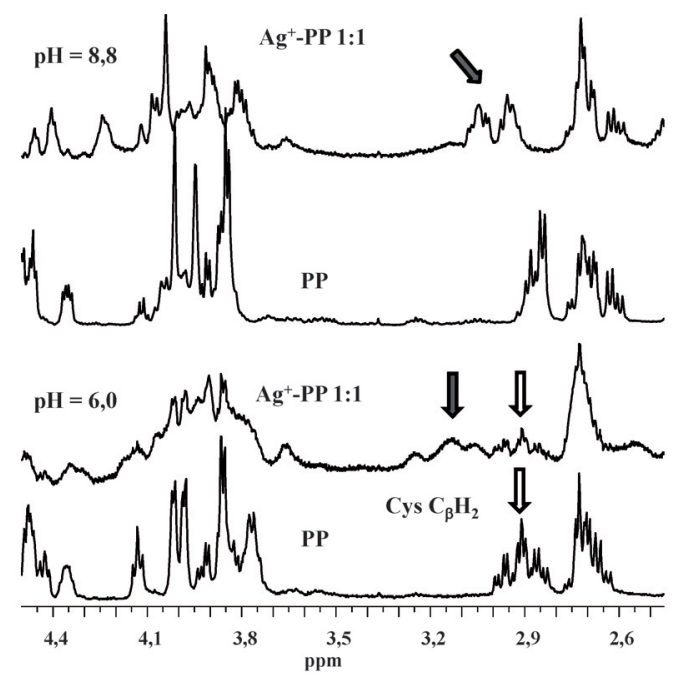

7. Ábra. Az PP ${ }^{1} \mathrm{H}-\mathrm{NMR}$ spektrumának részletei $\mathrm{Ag}^{+}$-ionok jelen és távollétében kétféle $\mathrm{pH}-\mathrm{n}$. Az üres nyilak a nem kötött, míg a teli nyilak az $\mathrm{Ag}^{+}$-ionokhoz kötött Cys egységek $\mathrm{CH}_{2}$ rezonanciáit mutatják. 
A $\mathrm{p} K_{\mathrm{s}} \sim 6,5$ értékkel jellemezhető deprotonálódást kísérő viszonylag kicsi abszorbancia növekedés felveti annak lehetőségét is, hogy a már savas körülmények között tiolátként kötődő Cys mellett a másik Cys egység oldallánca $\mathrm{pH} \sim$ 6-ig protonált, tiol formában koordinálódik az $\mathrm{Ag}^{+}$-ionhoz. A protonált tiolcsoport $\mathrm{Ag}^{+}$-koordinációja ugyan nem gyakori, de van rá példa az irodalomban. ${ }^{37} \mathrm{~A}$ \{Cys-S-,Cys-SH\} típusú kötésmód CueR fehérje fémkötő centrumában is racionális lehetőség, aminek jelentős szerepe lehet a molekula müködési mechanizmusában. ${ }^{31}$

\subsection{A CueR modellpeptidek vizsgálatával nyert eredmények hasznosíthatósága}

A fémion - oligopeptid rendszerek vizsgálatának legjelentősebb eredménye, hogy a modellezett CueR egy- és kétértékü fémionokkal szemben mutatott eltérő viselkedését a peptidek szintjén is ki tudtuk mutatni. Ez egyrészt komoly lépés a CueR fémion-felismerő mechanizmusának megértése felé, másrészt lehetőséget teremt arra, hogy a felismerő mechanizmus révén fluoreszcenciás jelet produkáló, genetikailag módosított baktériumokat tervezzünk, melyek egy adott fémionra hangolható szelektív fémion-érzékelőként müködhetnek. Csoportunkban jelenleg is folynak kutatások ebben az irányban. Az eredmények másik tanulsága, hogy a CueR fémkötő szakasza által inspirált flexibilis molekuláknál rigidebb szerkezetek szükségesek a fémion-szelektivitás jobb módosíthatóságához, ugyanakkor a $\mathrm{Hg}^{2+}$-ionok által kialakított hurokszerü szerkezet optimális lehet FRET fluoreszcenciás érzékelők fejlesztéséhez.

\section{Az AfArsR fehérje As(III)-kötő szakaszát modellező peptid vizsgálata}

Az Acidithiobacillus ferrooxidans baktériumban található ArsR arzén szabályzó fehérje a $C$-terminus-hoz közeli flexibilis fragmensén található három Cys tiolátcsoportjai révén köti az As(III)-at. ${ }^{38}$ Ez a (fél)fémkötő szakasz azért keltette fel csoportunk érdeklődését, mert modellszámítások alapján a megkötődés folyamatában először két szomszédos Cys egység kapcsolódik az As(III)-hoz, majd ez elösegíti a harmadik, távolabbi Cys-tiolát koordinációját. ${ }^{38}$ Ennek révén a molekula As(III)-at nem kötő állapotában egymástól távol elhelyezkedő fragmensek a félfém megkötésének hatására kerülnek közel egymáshoz. Ez ideálisnak tünt egy FRET hatáson alapuló fémion-szenzor kialakításához, melyben a három Cys biztosíthatná a nagy affinitású kötőhelyet toxikus „szoft” karakterü fémionok számára (8. Ábra). Ebből a célból állítottuk elö az Ac-WGENCCHGTRDCAG-Dans (ArsWD) szekvenciájú oligopeptidet, melyben az $N$-terminális Trp, illetve $C$-terminális danzilcsoport 3, ill. 2 aminosav hosszúságú „spacer”-en keresztül kapcsolódik a két, terminusokhoz közelebb eső ciszteinhez. Az aminosav kódok jelentése: W: Trp, G: Gly, E: Glu; N: Asn, C: Cys, H: His, T: Thr, R: Arg, D: Asp, A: Ala.

Eredményeink tárgyalása előtt azonban érdemes kritikailag áttekinteni néhány, az ArsWD-nél rövidebb, fluorofór-párral jelzett peptid fluoreszcenciás viselkedését bemutató munkát, és az ezekben levont következtetéseket.

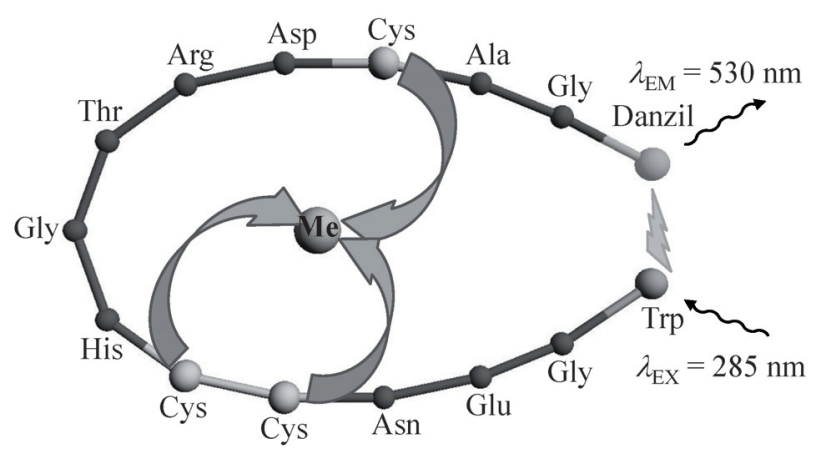

8. Ábra. Az AfArsR As(III)-kötőhelyéről mintázott oligopeptid (ArsWD) szekvenciája, és a fémion-kötés hatására remélt FRET effektus

\subsection{Rövid láncú flurofór-párral jelzett oligopeptidek, mint FRET elven müködő fémion szenzorok?}

A szakirodalomban több közlemény tárgyal olyan rövid láncú oligopeptideket, melyekben a Trp (W) / Danzil (Dans) fluorofór pár vagy közvetlenül a néhány aminosavból álló fémion-kötő fragmenshez kapcsolódik, vagy attól egy-két aminosavval távolabb található, pl. Dans-HPGHWG-NH $2,{ }^{39}$ Dans-CPGCW-NH ${ }_{2}{ }^{40}$ A szerzők különböző fémionok hatására jelentős fluoreszcencia intenzitás-növekedést mutattak ki a danzilcsoportra jellemző hullámhossztartományban (=500-550 nm között) függetlenül attól, hogy a danzilcsoport vagy a triptofán abszorpciós sávján gerjesztették a rendszereket. Utóbbi esetben az intenzitás növekedését a szerzők a fémionok által indukált FRET jelenségként azonosították.

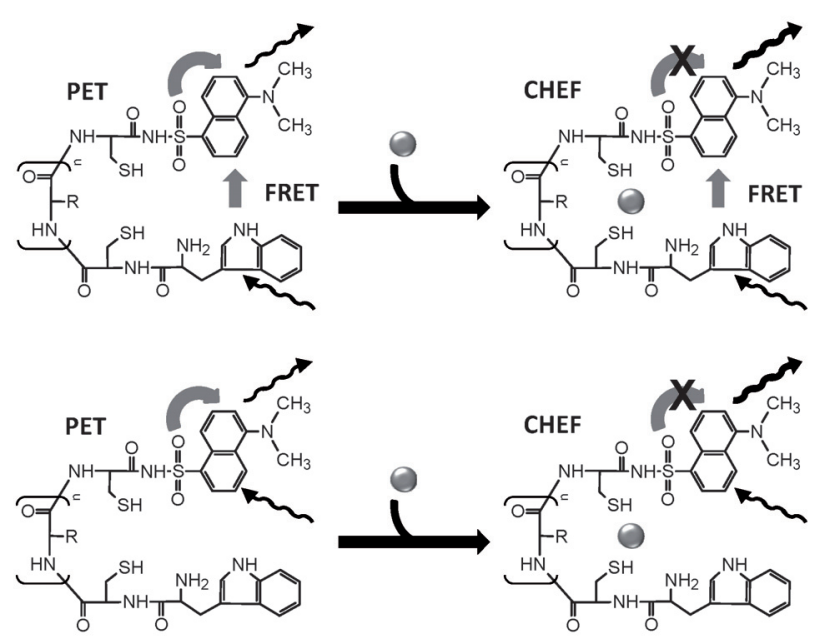

9. Ábra. Fémion-indukált PET gátlás az egymáshoz közeli Trp/Dans fluorofór párt tartalmazó oligopeptidekben, és a CHEF/FRET effektusok relatív hatása

A molekulák azonban egyértelműen túl kicsik ahhoz, hogy a két fluorofór csoport a szabad peptidekben a Förstertávolságon kívül ${ }^{41}$ legyen egymástól. Ez azt jelenti, hogy fémionok távollétében is létrejöhet rezonancia energia transzfer a Trp donor és a danzil akceptor között. Ezt a szerzők által bemutatott, fémiont nem tartalmazó oldatokról felvett fluoreszcencia spektrumok is bizonyítják: a Trp egységet gerjesztve gyakorlatilag alig látszik a Trp emissziós 
sávja 340 nm környékén, míg a danzilcsoport emissziója jelentős. A fémionok jelenlétében a két fluorofór közeledéséből fakadó extra FRET hatás, ha nem is elhanyagolható, de valószínüleg csekély. A szerzők feltehetőleg a fémion megkötődés által előidézett PET kikapcsolás (lásd Bevezető) következményét, azaz CHEF effektust figyelnek meg, melyhez jelentősen hozzájárulhat a danzilcsoport abszorpciós sávjainak eltolódása (a danzilcsoport számottevően gerjeszthető lehet a Trp gerjesztésére használt hullámhosszon is). Ezeket a feltételezhető effektusokat szemlélteti a 9. Ábra.

\subsection{Az ArsWD kölcsönhatása $\mathrm{Zn}^{2+}-, \mathrm{Cd}^{2+}$ és $\mathrm{Hg}^{2+}$-ionokkal}

A ligandum kölcsönhatását a 12. elemcsoport fémionjaival UV-pH titrálásokkal és spektrofluorimetriával tanulmányoztuk. A tiolátfémion töltésátviteli sávok megjelenésének, illetve intenzitás-változásának követését megnehezítette, hogy a jelentős tagszámú peptidnek, elsősorban a triptofán és danzil egységek miatt, jelentős elnyelése van $=210-250 \mathrm{~nm}$ között. Ez limitálta a mintákban beállítható koncentrációt, ugyanakkor kis koncentrációk mellett kicsi a fémion-koordináció okozta effektus is. Ez a $\mathrm{Zn}^{2+}$-ionok esetében gyakorlatilag meggátolta, hogy a komplexképződéssel kapcsolatban lényegi információhoz jussunk. A $\mathrm{Cd}^{2+}$-ArsWD rendszerben a fémion-koordinációval párhuzamosan csapadék képződött, így csak ligandum felesleg jelenlétében, $\mathrm{pH} \sim 8$ felett végeztünk méréseket, ilyen körülmények között ugyanis a csapadék feloldódott. A csapadék feloldódása ligandum felesleg mellett, valamint a bázikus $\mathrm{pH}$-tartományban tapasztalt szignifikáns abszorbancia különbség $245 \mathrm{~nm}$ környékén a szabad ligandum elnyeléséhez képest bisz-komplexek képződésére utal. Ennek jelét a másik két fémion esetében nem tapasztaltuk, ami nem meglepő a peptid mérete, és a jelentős számú potenciális donorcsoport jelenléte miatt (3Cys,His,Asp,Glu). A CueR fehérje fémion-kötő szakaszát modellező peptidekhez hasonlóan az ArsWD is már $\mathrm{pH}=2$ körül megköti a $\mathrm{Hg}^{2+}$-ionok teljes mennyiségét $1: 1$ fémion-ligandum arány mellett. $\mathrm{A} \mathrm{Hg}^{2+}$-ArsWD $1: 1$ rendszerben semleges $\mathrm{pH}$ felett 240-290 nm hullámhossz-tartományban jelentkező karakterisztikus abszorbancia növekedés a $\mathrm{Hg}^{2+}$ koordinációs szférájának átrendeződésére utal. Míg savas körülmények között két Cys-tiolát koordinációja valószínüsíthető, $\mathrm{pH} 7$ felett a harmadik Cys is részt vehet a $\mathrm{Hg}^{2+}$-megkötésében. ${ }^{42,43}$ Ilyen jellegű $\mathrm{pH}$-függő $\left\{2 \mathrm{~S}^{-}\right\} \rightarrow\left\{3 \mathrm{~S}^{-}\right\}$koordinációs mód változást más szerzők is leírtak a $\mathrm{Hg}^{2+}$-ionokat és három cisztein-tartalmú oligopeptideket tartalmazó rendszerekben. ${ }^{44}$

Az elmondottak tükrében rendkívül meglepő, hogy a remélt fluoreszcencia erősítő hatást a fémionok jelenlétében egyetlen kivételtől eltekintve - nem tapasztaltuk. A $\mathrm{Hg}^{2+}$-ionok, annak ellenére, hogy semleges $\mathrm{pH}$ felett képesek a három ciszteinhez koordinálódni, enyhe kioltást okoztak mind a Trp, mind a danzilcsoport fluoreszcenciájára. A $\mathrm{Hg}^{2+}, \mathrm{Pb}^{2+}$ és egyéb nehézfém elemeknél ez gyakran megfigyelt jelenség, ${ }^{45,46}$ noha az ArsWD esetében bízni lehetett abban, hogy a fémion nem kerül a fluorofór csoportok közvetlen környezetébe. A $\mathrm{Cd}^{2+}$-ArsWD 0,5:1 összetételü mintákban egészen bázikus körülmények mellett 283 nm-en történő gerjesztést alkalmazva a danzilcsoport emissziójának látványos növekedését figyeltük meg (10. Ábra). Ilyen változás $\mathrm{Cd}^{2+}$-ionok távollétében nem történik. A megfigyelt FRET-jellegü effektust minden valószínűség szerint két ligandum együttes koordinációja eredményezi a $\mathrm{Cd}^{2+}$-ionhoz, melynek révén a Trp és Danzil egységek a FRET hatótávolságán belül kerülnek egymáshoz. A két ligandum együttes koordinációját igénylő rendszereknek azonban csekély gyakorlati alkalmazhatósága lehet egy immobilizálást igénylő érzékelő fejlesztésénél.

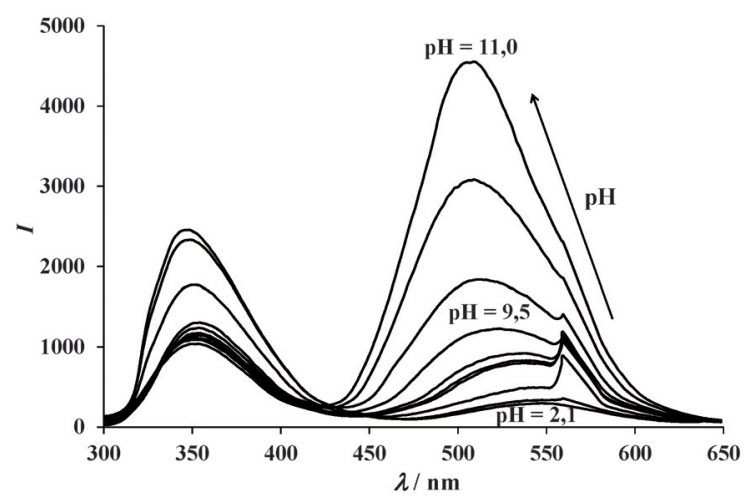

10. Ábra. Fluoreszcencia spektrumok a $\mathrm{Cd}^{2+}-\mathbf{A r s W D} 0,5: 1$ rendszerben a $\mathrm{pH}$ függvényében $\left(\mathrm{ex}=283 \mathrm{~nm}, c_{\mathrm{ArsWD}}=1,3510^{-5} \mathrm{M}\right)$

Tapasztalataink és az irodalmi adatok áttekintése arra utalnak, hogy tényleges FRET effektuson alapuló oligopeptid receptorra épülő fémion érzékelőt a fluorofór egységek fémion-kötőhelytől távolabbi elhelyezésével lehetne kialakítani, és a molekulatervezésnél érdemes számítógépes modellszámításokra támaszkodni.

\section{Az Ac-YCSSCY szekvenciájú szilárd hordozón rögzített hexapeptid $\mathrm{Cd}^{2+}$-kötésének vizsgálata ${ }^{47}$}

A CXXC szekvencia (ahol X bármilyen aminosavat jelöl) a metallotioneninek mellett fémion szállító-, raktározó-, ill. dajkafehérjékben egyaránt előfordul. Egyebek mellett a $\mathrm{Hg}^{2+}$-kötő MerP, ${ }^{48}$ a bakteriális vagy humán ATP7A és ATP7B fehérjék, ${ }^{49}$ ill. a réz-chaperon bakteriális Atx1, vagy az ezzel analóg humán Atox $1(\mathrm{HAH} 1)^{50}$ is ezt a szekvenciát alkalmazza „szoft” karakterü fémionok megkötésére. A természetes szekvenciák alapján tervezte meg csoportunk azt a hexapeptid molekulát, melyben a CXXC fragmens középső két aminosavjának helyére a vegyület hidrofil karakterét növelő $\mathrm{S}$ (Ser) egységek, míg a terminális pozíciókba Y (Tyr) aminosavak kerültek. A tirozin aminosavak, noha nem a legjobb természetes fluorofórok, a vegyület oldhatóságának biztosítása szempontjából jó választásnak tüntek. Érdemes azt is leszögezni, hogy a hexapeptid (YY) előállításával nem egy kiváló fémion-szelektivitású receptor molekula kialakítása volt a cél, sokkal inkább a szilárd hordozókon történő rögzítés lehetőségét, illetve az immobilizált vegyület viselkedését terveztük feltárni a rendkívül egyszerü ligandum segítségével. 


\subsection{A hidrofil karakterü gyantán rögzített YY peptid (YY-NTG) Cd ${ }^{2+}$-kötő képessége}

Az előzetes reményekkel ellentétben a vegyület vízoldhatósága nem volt elegendően nagy ahhoz, hogy részletes oldatfázisú vizsgálatokat végezzünk, és ilyen módon is karakterizáljuk a ligandum fémion-affinitását. Fluoreszcenciás mérések elvégzéséhez megfelelő koncentrációt ugyanakkor el tudtunk érni, s ezzel a kísérlettel igazolni tudtuk, hogy a fémion-kötés fluoreszcenciásan követhető, koncentráció arányos kioltást eredményez (11. Ábra).

Az YY hexapeptidet egy jó duzzadási karakterü hidrofil gyantára (Novasyn TG amino resin) felépítettük, majd tanulmányoztuk az érintkeztetési idő, az összeállított minták kiindulási $\mathrm{pH}$-ja és a $\mathrm{Cd}^{2+}$-koncentráció hatását a fémion-kötési sajátságokra. Eredményeink alapján 30 perc minden esetben elegendő volt a kötő-helyek telítéséhez és ezt követően már nem csökkent a minták ICP-MS módszerrel visszamért $\mathrm{Cd}^{2+}$-koncentrációja. Az összeállított minták pH-jának növelése $\mathrm{pH} \sim 4$-5-ig növelte a megkötött $\mathrm{Cd}^{2+}$-ion mennyiségét. A nagyobb $\mathrm{pH}$-értékeknél történő mérésekhez puffer oldatok alkalmazására volt szükség, ugyanis a kölcsönhatás okozta proton-disszociáció miatt a magasabb kezdeti pH-ra beállított minták a kísérlet ideje alatt jelentősen ( $\mathrm{pH} \sim 4,5$-ig) visszasavanyodtak. A gyanta elméleti kapacitásához képest 1,5-szörös feleslegben $\mathrm{Cd}^{2+}$-iont tartalmazó, HEPES segítségével $\mathrm{pH}=7,0$-re pufferelt mintából az YY-NTG 0,243 mg/10,0 mg (gyanta) kapacitással távolította el a fémionokat. Ez gyakorlatilag megegyezik a peptiddel módosított gyanta elméleti $\mathrm{Cd}^{2+}$-kötő képességével, ha ligandumonként 1 ekvivalens fémion koordinációját feltételezzük.

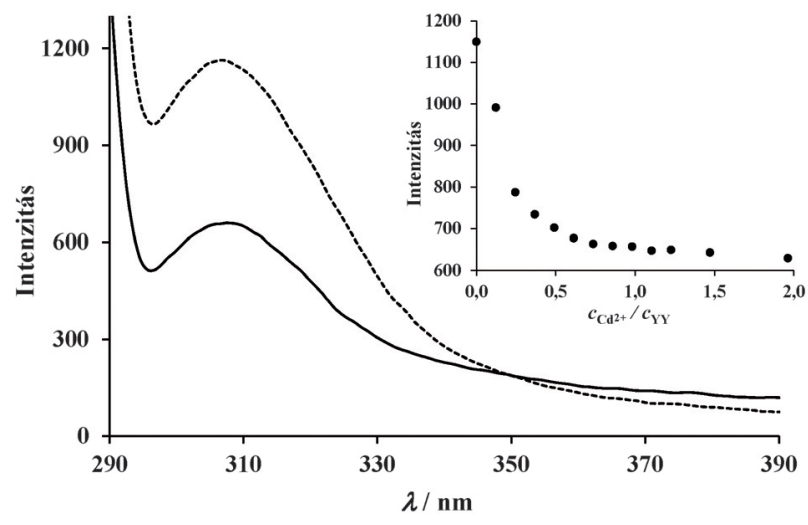

11. Ábra. Az YY ligandum fluoreszcencia spektruma $1 \mathrm{ekv} . \mathrm{Cd}^{2+}$-ion jelen- (folytonos vonal) és távollétében (szaggatott vonal) $(\mathrm{EX}=278 \mathrm{~nm}$, $\left.\mathrm{pH}=7,0, c_{\mathbf{Y Y}}=1,010^{-5} \mathrm{M}\right)$. A belső ábra a $308 \mathrm{~nm}$-en mért fluoreszcencia intenzitásának csökkenést mutatja a $\mathrm{Cd}^{2+}:$ YY arány függvényében. ${ }^{47}$

A módosított gyanta kimért mennyiségét savas oldatban $\mathrm{Cd}^{2+}$-ionok távol- és jelenlétében folyamatos kevertetés mellett $\mathrm{NaOH}$ mérőoldattal is megtitráltuk. A homogén oldatokhoz viszonyítva lassabban lejátszódó folyamatok miatt hosszabb várakozási időkkel dolgoztunk. Figyelembe véve egy ilyen mérés extrém körülményeit, a szilárd-folyadék határfelületen lejátszódó folyamatokat, az ionerősség beállításának problémáját és az egyéb technikai nehézségeket, a titrálásokkal nyert adatok jó becslésként kezelendők. Meg kell ugyanakkor említeni, hogy sem a titrálási görbék jellege, sem a kiértékelésükkel nyert képződési állandók ${ }^{47}$ nem utaltak a ligandumok közeli elhelyezkedéséből esetlegesen adódó polielektrolit-hatásra.

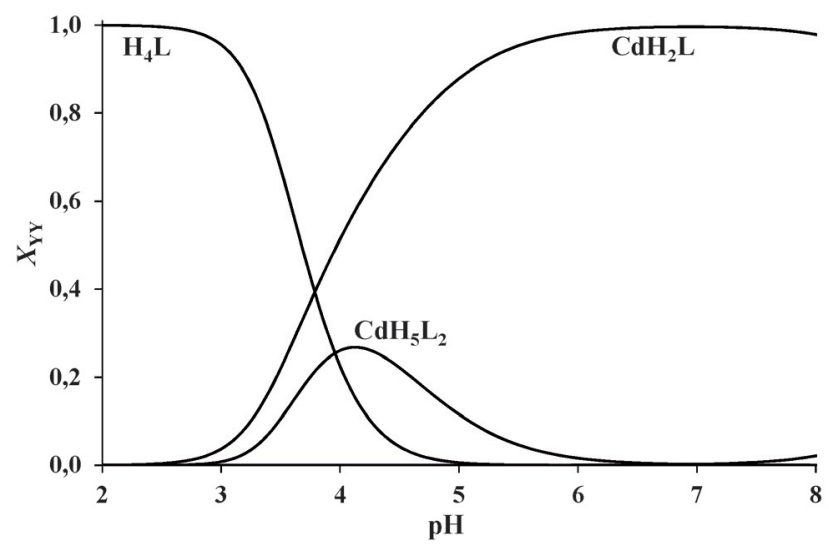

12. Ábra. Az YY megoszlása a különböző $\mathrm{Cd}^{2+}$-iont kötő formák között a $\mathrm{pH}$ függvényében, a fémion-kötő vizsgálatoknál alkalmazott koncentráció-arányra számolva: $\mathrm{Cd}^{2+}: \mathbf{Y Y}=0,66: 1, c_{\mathrm{Cd}^{2+}}=1,4410^{-4} \mathrm{M}$. ( $\mathrm{L}$ a teljesen deprotonált ligandumot, míg $\mathrm{H}$ a protont jelöli.) ${ }^{47}$

A titrálások révén meghatározott protonálódási és komplexképződési állandók jó összhangban vannak a $\mathrm{Cd}^{2+}$-megkötődés vizsgálatok eredményeivel. A legtöbb kísérletnél használt $\mathrm{Cd}^{2+}:$ YY-NTG 0,66:1 arányra, illetve az ilyen összetételü minták koncentrációira szimulált eloszlásgörbe (12. Ábra) jól szemlélteti, hogy a komplexképződési folyamatok már $\mathrm{pH} 3$ felett megindulnak, és $\mathrm{pH} \sim 6$ 6-ra az YY ligandum kínálta kötőhelyek 1 ekv. $\mathrm{Cd}^{2+}$-ion koordinálódásával telítődnek. Fontos megjegyezni, hogy ez a telítés már a $1: 1 \mathrm{Cd}^{2+}:$ YY-NTG aránynál is megtörténik.

A stabilitási adatok alapján az YY-NTG $\mathrm{Cd}^{2+}$-kötésének erősségét $\mathrm{pH}=7,0$-nél jellemző látszólagos stabilitási állandó is számolható. Ennek értéke $\lg K^{\prime}=10,1$, amely kiemelkedő fémion-affinitást jelez. Ezt szemlélteti a 2. Táblázatban feltüntetett néhány, két cisztein tartalmú oligopeptid $\mathrm{Cd}^{2+}$-komplexére vonatkozó állandóval való összevetés. A látványos stabilitásbeli különbség a vegyület rögzítésének hatása, ami a peptidek $\mathrm{Cd}^{2+}$-ionok megkötődését elősegítő orientációját indukálhatja.

2. Táblázat. Két ciszteint tartalmazó oligopeptidek $\mathrm{Cd}^{2+}$-kötő képességét jellemző látszólagos stabilitási állandók $(\mathrm{pH}=7,0, T=298 \mathrm{~K})$. Az adatok vizes oldatbeli mérésekre vonatkoznak, ellentétben az YY-NTG-vel.

\begin{tabular}{|c|c|c|}
\hline Ligandum & $\lg K^{\prime}(\mathrm{pH}=7,0)$ & Referencia \\
\hline Ac-GCASCDNARAAKK-NH & 7,96 & 51 \\
\hline $\mathrm{Ac}-\mathrm{CPCP}-\mathrm{NH}_{2}$ & 8,39 & 52 \\
\hline Ac-MTCSGCSRPG-NH & 8,30 & 53 \\
\hline e(GMTCSGCSRP) & 9,20 & 53 \\
\hline YY-NTG & 10,10 & 47 \\
\hline
\end{tabular}




\subsection{Az üveg és kvarc hordozókon rögzített hexapeptid fémion-kötő képessége}

Egy házilag épített reaktorban téglalap alakú kétoldalas üveg és kvarc lapokra is felépítettük az YY peptidet (13. Ábra). A kvarc lapokon a szilanizálást követő peptidszintézis 100 $\%$-os sikerességét feltételezve, a szilanolcsoportok becsülhető felületi borítottsága alapján a lapok elméleti $\mathrm{Cd}^{2+}$-kötö kapacitása $\sim 0,351 \mu \mathrm{g} \mathrm{Cd}{ }^{2+} /$ lapka.

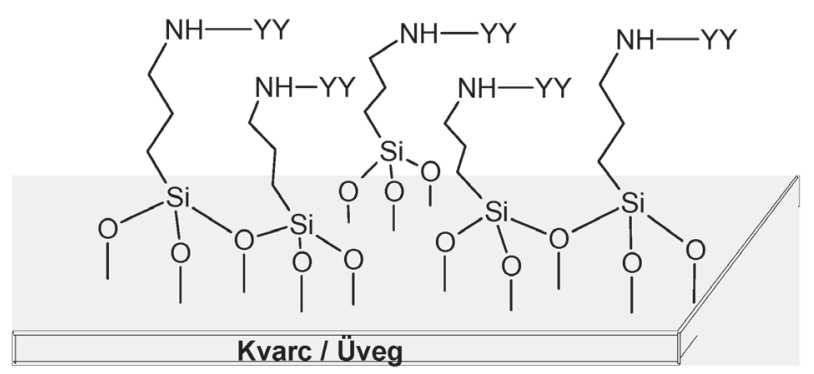

13. Ábra. Az üveg vagy kvarc lapon immobilizált hexapeptid felülethez való kapcsolódási módjának sematikus ábrázolása

A kvarclapokat egyenként 10,0 ml, 100 g/l koncentrációjú $\mathrm{Cd}^{2+}$-ion tartalmú oldatba helyeztük, melyek pH-ját HEPES pufferrel $\mathrm{pH}=7,0$-re állítottuk. Az így elkészített mintákból a reakció után a fémion koncentrációjának visszamérésével számolható $\mathrm{Cd}^{2+}$-kötő kapacitás 0,225 $\mu$ g-nak adódott, ami az elméleti érték 64,1 \%-a. Ez igazolja a szintézis folyamatának sikerességét, és egyúttal a hexapeptid, mint receptor molekula megfelelő müködését is.

\section{5. Összefoglalás}

Kutatásaink olyan, metalloproteinek fémkötőhelyei által inspirált, oligopeptidek kifejlesztését célozzák, melyek hatékony és szelektív fémion-kötő képessége kihasználható fémion-érzékelésre alkalmas rendszerek fejlesztéséhez. A CueR réz-efflux szabályzó fehérjék fémkötő doménjét modellező oligopeptidek vizsgálatával a fehérje müködési mechanizmusában is potenciálisan szerepet játszó különbséget tártunk fel az egyértékü $\mathrm{Ag}^{+}$-ion, illetve a kétértékü $\mathrm{Zn}^{2+}-, \mathrm{Cd}^{2+}$ - és $\mathrm{Hg}^{2+}$-ionok koordinációs módja között. Reményeink szerint az eredményeket egyaránt hasznosítani tudjuk fémion-receptor molekulák tervezésénél, illetve a CueR müködési mechanizmusán alapuló sejtes fémion-jelzőrendszer fejlesztésénél. Az AfArsR félfém-kötőhelyén alapuló, terminális pozíciókban Trp és danzilcsoportokkal jelzett oligopeptid vizsgálatával nyert tapasztalatok arra mutatnak, hogy egy jól müködő FRET szenzorhoz a fluorofór csoportok fémion-kötőhelytől távol(abb)i pozícionálása szükséges. A vizes oldatbeli vizsgálatok mellett egy CXXC motívumot tartalmazó hexapeptidet többféle szilárd hordozón rögzítve is elöállítottunk. Az immobilizált ligandum kiváló $\mathrm{Cd}^{2+}$-kötő képességet mutatott mind gyanta hordozón, mind kvarc és üveg mátrixokon. Ezzel igazoltuk a szintézisünk sikerességét, ill. annak alkalmazhatóságát további, hatékonyabb és szelektívebb fémion-megkötésre alkalmas molekulákra.

\section{Kísérleti rész}

\subsection{Előállított vegyületek}

A tanulmányozott, terminális pozíciókban védett (acetil és savamid) oligopeptideket az Fmoc stratégián alapuló szilárdfázisú szintézisse ${ }^{54}$ állítottuk elő Rink Amide AM gyantát alkalmazva. Az C-terminális helyzetben danzilcsoportot tartalmazó peptid elöállítása Dansyl NovaTag hordozón történt. A gyanta mátrixokon rögzített ligandumok szintéziséhez kiemelkedő sav-stabilitású, különböző duzzadási képességű hordozókat (benzhydrylamine resin - BHA-resinHCl ill. Novasyn TG amino resin) használtunk. A szintézis befejezésével az $N$-terminális aminocsoportokat acetil-védőcsoportokkal láttuk el, az oldallánci védőcsoportokat pedig 92\% v/v trifluorecetsav (TFA) tartalmú eleggyel hasítottuk. Az üveg, ill. kvarc hordozón történő peptidszintézishez az anyagok felületét egy oxidáló, erősen savas oldattal tisztítottuk (cc. $\mathrm{H}_{2} \mathrm{SO}_{4}$ és $30 \%$ v/v $\mathrm{H}_{2} \mathrm{O}_{2} 3: 1$ arányú keveréke), majd szárítást követően 10\% v/v (3-aminopropil)trietoxiszilán-t (APTES) tartalmazó vizes oldattal szilanizáltuk. Az APTES szabad aminocsoportjára módosított Fmoc-módszerrel ${ }^{55}$ építettük fel az oligopeptid láncokat. A szilárd hordozóról lehasított peptideket Shimadzu LC-20 típusú HPLC készüléken egy SUPELCO Discovery BIO Wide Pore C18 (25×10 mm, $5 \mathrm{~m})$ félpreparatív kolonna alkalmazásával tisztítottuk. A vegyületek előállításának részletei megtalálhatók az idézett hivatkozásokban. ${ }^{32,47}$

\subsection{Kísérleti módszerek}

pH-potenciometria: ${ }^{29-32,47}$ A ligandumok protonálódási és komplexképződési folyamatait vizes oldatokban pH-potenciometriás titrálásokkal követtük $(I=0,1 \mathrm{M}$ $\left.\mathrm{NaClO}_{4}, T=298,0 \pm 0.1 \mathrm{~K}\right)$. A gyantán rögzített oligopeptid vizsgálatakor $\sim 0,03 \mathrm{~g}$ tömegü peptiddel-dekorált gyantaszemcsét is kevertettünk a megtitrált mintákban. A titrálásokat számítógép által vezérelt, Dosimat 665 (Metrohm) automata bürettából, Orion 710A digitális pH-mérőből és Metrohm Micro pH üvegelektródból felépített automata titráló rendszerrel végeztük. A protonálódási és komplexképződési egyensúlyokat az alábbi általános folyamattal, és az arra vonatkozó képződési állandóval jellemeztük:

$$
\begin{aligned}
& \mathrm{pM}+\mathrm{qH}+\mathrm{rL} \rightleftharpoons \mathrm{M}_{\mathrm{p}} \mathrm{H}_{\mathrm{q}} \mathrm{L}_{\mathrm{r}} \\
& \beta_{\mathrm{M}_{\mathrm{p}} \mathrm{H}_{\mathrm{q}} \mathrm{L}_{\mathrm{r}}}=\frac{\mathrm{M}_{\mathrm{p}} \mathrm{H}_{\mathrm{q}} \mathrm{L}_{\mathrm{r}}}{[\mathrm{M}]^{\mathrm{p}}[\mathrm{H}]^{\mathrm{q}}[\mathrm{L}]^{\mathrm{r}}}
\end{aligned}
$$

Az egyenletekben $\mathrm{M}$ a fémiont, $\mathrm{H}$ a protonokat, míg $\mathrm{L}$ a ligandumot jelöli.

UV-Vis és CD-spektroszkópia: ${ }^{29-32}$ Az UV-Vis méréseket Shimadzu UV-3600 UV-VIS-NIR vagy Thermo Evolution 220 spektrofotométereken végeztük $1,0 \mathrm{~cm}$ úthosszú, teflon dugóval ellátott cellákban. A szinkrotron radiációs CD (SRCD) spektrumokat az Aarhusi Egyetemen, Dániában, az „SRCD facility at the CD1 beamline on the storage ring ASTRID at the Institute for Storage Ring Facilities (ISA) 
komplexumban vettük fel 0,1 mm úthosszú kvarc cellákat (SUPRASIL, Hellma GmbH, Germany) alkalmazva, 175-260 nm hullámhossz-tartományban.

Spektrofluorimetria: ${ }^{47}$ A fluorimetriás vizsgálatokat Hitachi-F4500 spektrofluoriméteren végeztük 1,0 cm × 1,0 cm méretü, Teflon dugóval ellátott kvarc cellát alkalmazva. $\mathrm{Az}$ emissziós spektrumokat az adott fluorofór(pár)nak megfelelő hullámhossz-tartományban és gerjesztési hullámhosszak alkalmazásával vettük fel (tirozin: ${ }_{\mathrm{EX}}=278$ $\mathrm{nm},{ }_{\mathrm{EM}}=285-400 \mathrm{~nm}$; triptofán: ${ }_{\mathrm{EX}}=283 \mathrm{~nm},{ }_{\mathrm{EM}}=$ 295-700), rendszerint $5 \mathrm{~nm}$ és $10 \mathrm{~nm}$ slit-eket alkalmazva a gerjesztő, illetve emittált fénysugárra. A spektrumokat az önabszorpció és a belső filter hatások figyelembevételével korrigáltuk. $^{41}$

1H-NMR spektroszkópia:29-32 A 1H-NMR méréseket 500,132 MHz-es Bruker Avance DRX 500 spektrométeren végeztük. A spektrumokat $T=298 \mathrm{~K}$ hőmérsékleten, rendszerint $\mathrm{H}_{2} \mathrm{O}: \mathrm{D}_{2} \mathrm{O} 90: 10 \%$ v/v oldószerben vagy tiszta $\mathrm{D}_{2} \mathrm{O}$-ban vettük fel a zgpr vagy zgcppr pulzus szekvenciát alkalmazva a $\mathrm{H}_{2} \mathrm{O} / \mathrm{HDO}$ rezonanciák preszaturációja céljából. A $\mathrm{D}_{2} \mathrm{O}$-ban végzett méréseknél a $\mathrm{pH}^{*}$ értékek (a deutérium-effektussal nem korrigált pH-méter leolvasás) beállítását $\mathrm{NaOD}$ adagolásával végeztük.

ICP-MS: ${ }^{47}$ A szilárd hordozókon immobilizált peptidek fémion-megkötő képességének vizsgálatához a minták fémion-koncentrációjának meghatározását egy Agilent 7700x ICP-MS készülékkel végeztük. A többpontos kalibrációs görbék felvételéhez kereskedelmi forgalomban kapható standard oldatokat (Inorganic Ventures) és nyomelem analitikai tisztaságú ioncserélt vizet (Millipore Elix Advantage $5+$ Synergy) alkalmaztunk. Az adatok értékeléséhez a ${ }^{111} \mathrm{Cd}$ tömegcsúcsát használtuk.

A különböző rendszerek vizsgálatakor alkalmazott kísérleti körülményeket, müszerbeállításokat és egyéb technikai részleteket a módszerek neve mellett megjelölt hivatkozások tartalmazzák.

\section{Köszönetnyilvánítás}

A szerzők ezúton mondanak köszönetet az összefoglalt munkákat tartalmazó angol nyelvü közlemények társszerzőinek, valamint az anyagi támogatásért az alábbi forrásoknak: OTKA NKTH CK 80850, TÁMOP 4.2.1/B-09/1/KONV-2010-0005, EGT és a Norvég Finanszírozási Mechanizmus (Magyari Zoltán Posztdoktori Ösztöndíj 2010), FP7/2007-2013 Grant No. 226716, HURO/1001/232/2.2.2. (METCAP), MTA Bolyai János Kutatási Ösztöndíj 2011-2014, FP7/2007-2013, Grant No. 312284, ISOLDE/CERN beam time grants IS448 and IS488, Danish Council for Independent Research (Nature and Universe) of the Ministry for Higher Education and Science NICE grant.

\section{Hivatkozások}

1. Sparks, D. L. Elements 2005, 1, 193-197. https://doi.org/10.2113/gselements.1.4.193

2. Bargossi, C.; Fiorini, M. C.; Montalti, M.; Prodi, L.; Zaccheroni, N. Coord. Chem. Rev. 2000, 208, 17-32. https://doi.org/10.1016/S0010-8545(00)00252-6

3. Formica, M.; Fusi, V.; Giorgi, L.; Micheloni, M. Coord. Chem. Rev. 2012, 256, 170-192.

https://doi.org/10.1016/j.ccr.2011.09.010

4. Valeur, B.;Leray, I. Coord. Chem. Rev. 2000, 205, 3-40. https://doi.org/10.1016/S0010-8545(00)00246-0

5. Prodi, L.; Bolletta, F.; Montalti, M.; Zaccheroni, N. Coord. Chem. Rev. 2000, 205, 59-83.

https://doi.org/10.1016/S0010-8545(00)00242-3

6. Jiang, P.; Guo, Z. Coord. Chem. Rev. 2004, 248, 205-229. https://doi.org/10.1016/j.cct.2003.10.013

7. Imperiali, B.; Pearce, D. A.; Sohna Sohna, J.-E.; Walkup, G.; Torrado, A. SPIE Proc. Fallahi, M.; Swanson, B.I., Ed. Boston, MA, 1999, pp 135-143. https://doi.org/10.1117/12.372909

8. Verma, N.; Singh, M. BioMetals 2005, 18, 121-129. https://doi.org/10.1007/s10534-004-5787-3

9. Liu, Q.; Wang, J.; Boyd, B. J. Talanta 2015, 136, 114-127. https://doi.org/10.1016/j.talanta.2014.12.020

10. Dutta, M.; Das, D. Trends Anal. Chem. 2012, 32, 113-132. https://doi.org/10.1016/j.trac.2011.08.010

11. Carter, K. P.; Young, A. M.; Palmer, A. E. Chem. Rev. 2014, 114, 4564-4601. https://doi.org/10.1021/cr400546e

12. Pazos, E.; Vázquez, O.; Mascareńas, J. L.; Vázquez, M. E. Chem. Soc. Rev. 2009, 38, 3348-3359. https://doi.org/10.1039/b908546g

13. Afaneh, A. T.; Schreckenbach, G. J. Phys. Chem. A 2015, 119, 8106-8116. https://doi.org/10.1021/acs.jpca.5b04691

14. Joshi, B. P.; Lohani, C. R.; Lee, K.-H. Org. Biomol. Chem. 2010, 8, 3220-3226. https://doi.org/10.1039/b925744f

15. Kim, J.-M.; Lohani, C. R.; Neupane, L. N.; Choi, Y.; Lee, K.-H. Chem. Commun. 2012, 48, 3012-3014. https://doi.org/10.1039/c2cc16953c

16. Wang, P.; Liu, L.; Zhou, P.; Wu, W.; Wu, J.; Liu, W.; Tang, Y. Biosens. Bioelectron. 2015, 72, 80-86. https://doi.org/10.1016/j.bios.2015.04.094

17. Neupane, L. N.; Thirupathia, P.; Janga, S.; Jang, M. J.; Kim, J. H.; Lee, K.-H. Talanta 2011, 85, 1566-1574. https://doi.org/10.1016/j.talanta.2011.06.052

18. Torrado, A.; Walkup, G. K.; Imperiali, B. J. Am. Chem. Soc. 1998, 120, 609-610. https://doi.org/10.1021/ja973357k

19. Godwin, H. A.; Berg, J. M.; J. Am. Chem. Soc. 1996, 118, 6514-6515. https://doi.org/10.1021/ja961184d

20. White, B. R., Liljestrand, H. M.; Holcombe, J. A. Analyst 2008, 133, 65-70. https://doi.org/10.1039/B711777A

21. Fegley, M. E. A.; Pinnock, S. S.; Malele, C. N.; Jones Jr., W. E. Inorg. Chim. Acta 2012, 381, 78-84. https://doi.org/10.1016/j.ica.2011.11.040

22. Joshi, B. P.; Park, J.-Y.; Lee, K.-H. Sensors Actuators B Chem. 2014, 191, 122-128. https://doi.org/10.1016/j.snb.2013.09.075

23. Ma, Z.; Jacobsen, F. E.; Giedroc, D. P. Chem. Rev. 2009, 109, 4644-4681. Https://doi.org/10.1021/cr900077w 
24. Waldron, K. J.; Rutherford, J. C.; Ford, D.; Robinson, N. J. Nature, 2009, 460, 823-830.

https://doi.org/10.1038/nature08300

25. Waldron K. J.; Robinson, N. J. Nat. Rev. Microbiol. 2009, 6, 25-35. https://doi.org/10.1038/nrmicro2057

26. Brown, N. L.; Stoyanov, J. V.; Kidd, S. P.; Hobman, J. L. FEMS Microbiol. Rev. 2003, 27, 145-163. https://doi.org/10.1016/S0168-6445(03)00051-2

27. Outten, F. W.; Outten, C. E.; Hale, J.;. O'Halloran, T. V J. Biol. Chem. 2000, 275, 31024-31029. https://doi.org/10.1074/jbc.M006508200

28. Changela, A.; Chen, K.; Xue, Y.; Holschen, J.; Outten, C. E.; O’Halloran, T. V.; Mondragón, A. Science, 2003, 301, 1383-1387. https://doi.org/10.1126/science. 1085950

29. Jancsó, A.; Gyurcsik, B.; Mesterházy, E.; Berkecz, R.; J. Inorg. Biochem. 2013, 126, 96-103. https://doi.org/10.1016/j.jinorgbio.2013.05.019

30. Szunyogh, D.; Gyurcsik, B.; Larsen, F. H.; Stachura, M.; Thulstrup, P. W.; Hemmingsen, L.; Jancsó, A. Dalton Trans. 2015, 44, 12576-12588. https://doi.org/10.1039/C5DT00945F

31. Szunyogh, D.; Szokolai, H.; Thulstrup, P. W.; Larsen, F. H.; Gyurcsik, B.; Christensen, N. J.; Stachura, M.;

Hemmingsen, L.; Jancsó, A.; Angew. Chem. Int. Ed. 2015, $54,15756-15761$. https://doi.org/10.1002/anie.201508555

32. Jancsó, A.; Szunyogh, D.; Larsen, F. H.; Thulstrup, P. W.; Christensen, N. J.; Gyurcsik, B.; Hemmingsen, L. Metallomics 2011, 3, 1331-1339. https://doi.org/10.1039/c1mt00138h

33. Szunyogh, D. Ph.D. értekezés, Szegedi Tudományegyetem, 2016.

34. Kagi, J. H. R.; Vasak, M.; Lerch, K.; Gilg, D. E. O.; Hunziker, P.; Bernhard, W. R.; Good, M. Environ. Health. Perspect. 1984, 54, 93-103. https://doi.org/10.2307/3429795

35. Wright, J. G.; Natan, M. J.; MacDonnell, F. M.; Ralston, D. M.; O'Halloran, T. V. In Progress in Inorganic Chemistry: Bioinorganic Chemistry, Lippard, S. J. Ed.; John Wiley \& Sons: New York, 1990, Vol. 38, pp. 323-412. https://doi.org/10.1002/9780470166390.ch6

36. Bebout, D. C. In Encyclopedia of Inorganic and Bioinorganic Chemistry, John Wiley \& Sons, Ltd. 2011, DOI: 10.1002/9781119951438.eibc0124. https://doi.org/10.1002/9781119951438.eibc0124

37. Bharti, A.; Bharati, P.; Bharty, M. K., Dani, R. K.; Singh, S.; Singh, N. K. Polyhedron 2013, 54, 131-139. https://doi.org/10.1016/j.poly.2013.02.035

38. Qin, J.; Fu, H.-L.; Ye, J.; Bencze, K. Z.; Stemmler, T. L.; Rawlings, D. E.; Rosen, B. P. J. Biol. Chem. 2007, 282, 34346-34355. https://doi.org/10.1074/jbc.M706565200
39. Wang, P.; Wu, J.; Zhou, P.; Liu, W.; Tang, Y. J. Mater. Chem. B, 2015, 3, 3617-3624. https://doi.org/10.1039/C5TB00142K

40. Li, Y.; Li, L.; Pu, X.; Mab, G.; Wang, E.; Kong, J.; Liu, Z.; Liu, Y. Bioorg. Med. Chem. Lett. 2012, 22, 4014-4017. https://doi.org/10.1016/j.bmcl.2012.04.088

41. Lakowicz, J. R. Principles of Fluorescence Spectroscopy, 3rd ed., Springer US: New York, 2006. https://doi.org/10.1007/978-0-387-46312-4

42. Pujol, A. M.; Lebrun, C.; Gateau, C.; Manceau, A.; Delangle, P. Eur. J. Inorg. Chem. 2012, 3835-3843. https://doi.org/10.1002/ejic.201200484

43. Łuczkowski, M.; Stachura, M.; Schirf, V.; Demeler, B.; Hemmingsen, L.; Pecoraro, V. L. Inorg. Chem. 2008, 47, 10875-10888. https://doi.org/10.1021/ic8009817

44. Iranzo, O.; Thulstrup, P. W.; Ryu, S. B.; Hemmingsen, L.; Pecoraro, V. L. Chem. Eur. J. 2007, 13, 9178-9190. https://doi.org/10.1002/chem.200701208

45. Joshi, B. P.; Park, J.; Lee, W. I.; Lee, K.- H. Talanta 2009, 78, 903-909. https://doi.org/10.1016/j.talanta.2008.12.062

46. White, B. R.; Liljestrand, H. M.; Holcombe, J. A. Analyst 2008, 133, 65-70. https://doi.org/10.1039/B711777A

47. Galbács, G.; Szokolai, H.; Kormányos, A.; Metzinger, A.; Szekeres, L.; Marcu, C.; Peter, F; Muntean, C.; Negrea, A.; Ciopec, M.; Jancsó, A.; Bull. Chem. Soc. Jpn. 2016, 89, 243-253. https://doi.org/10.1246/bcsj.20150333

48. Steele, R. A.; Opella, S. J. Biochemistry 1997, 36, 6885-6895. https://doi.org/10.1021/bi9631632

49. Forbes, J. R.; His, G.; Cox, D. W. J. Biol. Chem. 1999, 274, 12408-12413. https://doi.org/10.1074/jbc.274.18.12408

50. Rosenzweig, A. C. Chemistry \& Biology 2002, 9, 673-677. https://doi.org/10.1016/S1074-5521(02)00156-4

51. Krzywoszynska, K.; Rowinska-Zyrek, M.; Witkowska, D.; Potocki, S.; Luczkowski, M.; Kozlowski, H.; Dalton Trans. 2011, 40, 10434-10439. https://doi.org/10.1039/c1dt10562k

52. Kulon, K.; Woźniak, D.; Wegner, K.; Grzonka, Z.; Kozłowski, H. J. Inorg. Biochem. 2007, 101, 1699-1706. https://doi.org/10.1016/j.jinorgbio.2007.04.001

53. Rousselot-Pailley, P.; Sénčque, O.; Lebrun, C.; Crouzy, S.; Boturyn, D.; Dumy, P.; Ferrand, M.; Delangle, P. Inorg. Chem. 2006, 45, 5510-5520. https://doi.org/10.1021/ic060430b

54. Chan, W. C.; White, P. D. Fmoc solid phase peptide synthesis: a practical approach, Oxford University Press: Oxford, 2000.

55. Malachowski, L.; Stair, J.; Holcombe, J. A. Pure Appl. Chem. 2004, 76, 777-787. https://doi.org/10.1351/pac200476040777 


\section{Oligopeptide probes for toxic metal ion sensing, inspired by the metal binding domains of metalloproteins}

Toxic metal ions appear in the environment from natural and anthropogenic sources. The detection and removal of these ions is essential due to their potential adverse effects to every life form. Besides the well-known and broadly applied, robust analytical techniques used for the analysis of metal ions from environmental and biological fluids, an increasing attention is devoted to the development of novel, alternative detection techniques based on the use of chemical/biochemical sensors. A particularly interesting sub-category of chemical sensors utilize bioinspired molecules or systems as receptors that naturally possess the properties being essential for a sensory element: sensitivity and selectivity. Oligopeptides, proteins or even simple cells may be efficient receptors of (bio)chemical sensors, based on a response that is induced by their selective reactions with metal ions. Sensors based on synthetic oligopeptides are generally more expensive than full-cell based biosensors, however, the former ones could be developed and fine-tuned to bear outstanding sensitivity and selectivity. Besides, their applicability is much less limited in terms of the required conditions for an optimal operation, as compared to protein- or cell-based sensors. In recent years, our research group has been working on the synthesis and investigation of numerous cysteine containing oligopeptides that had been inspired by the metal binding domains of various metalloproteins (regulators, transporters, chaperons). Gaining a benefit from the large affinity of these sequences for soft metal ions, the modification of the ligands may lead to compounds that can be successfully used in the efficient and selective sensing of toxic metal ions. Introducing well-designed modifications (i.e. attaching fluorophore units into proper positions), these molecules may be capable for providing a metal-ion mediated response and at the same time their immobilization to solid matrices may also be possible. This publication provides a brief summary of our efforts and achievements within this field.

We have synthesized several, terminally protected, 12-mer oligopeptides possessing two cysteine residues close to their $C$ and $\mathrm{N}$-terminus. The amino acid sequences of these ligands are either identical to the metal binding domain of the bacterial metalloregulatory protein $\mathrm{CueR}^{27}$ (from E. coli or V. cholerae) or their slightly modified variants with amino acid substitutions at one or two positions. The transcriptional activator CueR displays an outstanding functional selectivity for the group eleven monovalent ions while it does not respond to $\mathrm{Zn}^{2+}$ or $\mathrm{Hg}^{2+} \cdot{ }^{28}$ It was shown that the coordination of the two cysteines from the metal binding loop of CueR, together with other interactions (H-bonding or electrostatic), restrict the bound monovalent metal ions into a linear coordination geometry. ${ }^{28}$

The major result of our studies on the various metal ion oligopeptide systems is a finding that the model ligands possess fundamentally distinct binding features for the monovalent ion $\mathrm{Ag}^{+}$and the divalent ions $\mathrm{Zn}^{2+}, \mathrm{Cd}^{2+}$ and $\mathrm{Hg}^{2+} \cdot{ }^{29-32}$ The binding of $\mathrm{Ag}^{+}$to the ligands under acidic conditions (even at $\mathrm{pH}=2$ ) was proved by UV-, CD- and ${ }^{1} \mathrm{H}-\mathrm{NMR}$ experiments, as well as pH-potentiometric titrations (Figure 6). ${ }^{31}$ Spectroscopic data suggest the coordination of at least one of the Cys-sidechain donors as a thiolate to $\mathrm{Ag}^{+}$in the $\mathrm{Ag}^{+}-\mathbf{P P} 1: 1$ system $(\mathbf{P P}=\mathrm{Ac}-$ SCPGDQGSDCPI-NH $\mathrm{N}_{2}$ ). However, a deprotonation process in the $\mathrm{pH}$-range of $\mathrm{pH} \sim 5.5-8$ can be clearly observed both on the $\mathrm{pH}$ - and UV-titration curves (Figure 6.) that can be attributed to the proton release of the second thiol group of the ligand. This $\mathrm{pH}$-dependent change in the coordination environment of $\mathrm{Ag}^{+}$, shown also by the recorded ${ }^{1} \mathrm{H}-\mathrm{NMR}$ spectra (Figure 7 ), represents a remarkable difference as compared to divalent metal ion - ligand systems where both cysteines are bound to the metal ions as thiolates at or below $\mathrm{pH} \sim 6$. The $\mathrm{Ag}^{+}$-promoted thiol-deprotonation ( $\mathrm{p} K_{\mathrm{a}} \sim 6.5$ ), vide supra, is accompanied by a modest change in the recorded absorbances, especially if compared to the absorbance increase induced by the addition of $\mathrm{Ag}^{+}$to the peptide under acidic conditions (Figure 6.). This may lead to an assumption that below $\mathrm{pH} \sim 6$ the second cysteine sidechain group is also bound to $\mathrm{Ag}^{+}$in its protonated form (as a thiol), besides the coordinated thiolate moiety. Indeed, a $\{$ Cys-S, Cys-SH $\}$ type coordination environment around the monovalent metal ions is also possible in the metal binding site of CueR. ${ }^{31}$ These results are an important step towards the deeper understanding of the mechanism of operation of the protein. At the same time, our findings also provide an opportunity for utilizing the complex recognition mechanism of the protein in the development of genetically modified bacteria that produce a fluorescence signal as a response to a specific metal ion and thus behave as a metal-responsive biosensor. There is an ongoing research in our group in this direction. Another experience of these studies is that more rigid structures, as compared to the flexible $\mathrm{CueR}$ model peptides, are needed for the efficient tuning of metal ion selectivity. Nevertheless, a loop structure formed by $\mathrm{Hg}^{2+}$ when binding to the ligands might be utilized in the development of FRET-based metal ion sensing molecules.

We have also studied an oligopeptide, comprising the arsenic-binding $C$-terminal flexible loop of the ArsR-family metalloid regulator protein AfArsR, encompassing three Cys residues for the binding of the regulated metalloids. We have introduced a Trp and a danysl unit as a fluorophore pair into the two termini of the ligand in order to initiate a FRET-response via metal ion chelation. (The sequence of the investigated ligand, ArsWD, is: Ac-WGENCCHGTRDCAG-Dans.) However, FRET-effect was observed only with $\mathrm{Cd}^{2+}$ and only in the presence of ligand excess at high $\mathrm{pH}(\mathrm{pH}>9)$. This is likely to be the result of bis-complex formation bringing the two fluorophores into close proximity. However, systems that require the simultaneous binding of two receptors to the metal ion have little, if any, applicability in sensory elements with immobilized receptors. Based on literature data and our own results, we believe that in order to obtain a real FRET-based metal ion sensing oligopeptide receptor one should position the fluorophore units in a larger (optimal) distance relative to the metal ion binding centre. Computational model calculations should assist the rational design of such molecules.

Besides aqueous studies we have also synthesized, on various solid supports, a hexapeptide ligand (YY: Ac-YCSSCY), encompassing the well-known CXXC-motif found in a number of metalloproteins. The two tyrosine residues were used as natural fluorophore units with less hydrophobic character as compared to tryptophane while the two serine units were introduced to provide reasonable water solubility for the ligand. In spite of this the solubility of the hexapeptide was not enough for detailed studies and for the characterization of the metal-binding affinity of the compound in aqueous solution. 
Nevertheless, we could perform a series of fluorescent measurements where the concentration ratio of $\mathrm{Cd}^{2+}$ and the peptide was systematically varied. These experiments revealed that the coordination of $\mathrm{Cd}^{2+}$-ions by the ligand could be monitored by this technique and that $\mathrm{Cd}^{2+}$-binding resulted in a concentration-dependent quenching of the tyrosine fluorescence (Figure 11). It is important to note that the YY hexapeptide was meant to be a simple fluorescent probe allowing us to investigate the possibilities of immobilization on various solid matrices and to study the metal binding features of a cysteine containing peptide in its immobilized form. Besides the $\mathrm{Cd}^{2+}$-capturing experiments where metal ion binding by the immobilized peptide was monitored ICP-MS we also performed
pH-potentiometric titrations with a resin-bound form of $\mathbf{Y Y}$ in the absence and presence of $\mathrm{Cd}^{2+}$-ions. The species distribution diagram, calculated from the formation constants of the various $\mathrm{Cd}^{2+}$-coordinated adducts of $\mathbf{Y Y}$, correlate well with the results of metal ion capturing experiments. These results demonstrate that $\mathrm{Cd}^{2+}$-binding occurs already from $\mathrm{pH} \sim 3$ and that the immobilized metal binding sites are filled by one equivalent of $\mathrm{Cd}^{2+}$ ion per ligand (Figure 12). In summary, the immobilized peptide showed an excellent $\mathrm{Cd}^{2+}$-binding property either when attached to a resin or to glass or quartz matrices. This finding verified the success of our synthetic approach and, at the same time, it also showed the feasibility of the procedure in the immobilization of more efficient metal-receptor candidates. 